\title{
ALKALOIDS AND ACETOGENINS IN ANNONACEAE DEVELOPMENT: BIOLOGICAL CONSIDERATIONS ${ }^{1}$
}

\author{
ALMA ROSA GONZÁLEZ-ESQUINCA², IVÁN DE-LA-CRUZ-CHACÓN³, \\ MARISOL CASTRO-MORENO ${ }^{4}$, JOSÉ AGUSTÍN OROZCO-CASTILLO 5 , \\ CHRISTIAN ANABI RILEY- SALDAÑA ${ }^{6}$
}

ABSTRACT - Chemical studies of the plant family Annonaceae have intensified in the last several decades due to the discovery of annonaceous molecules with medicinal potential (e.g., benzylisoquinoline alkaloids and acetogenins). Approximately 500 alkaloids have been identified in 138 Annonaceae species in 43 genera. In addition, until 2004, 593 annonaceous acetogenins (ACGs) had been identified, from 51 species in 13 genera.This suggests that plants from this family allocate important resources to the biosynthesis of these compounds. Despite the diversity of these molecules, their biological roles, including their physiological and/ or ecological functions, are not well understood. In this study, it was provided new data describing the variety and distribution of certain alkaloids and ACGs in annonaceous plants in distinct stages of development. The potential relationships among some of these compounds and the seasonally climatic changes occurring in the plant habitat are also discussed. These data will improve our understanding of the secondary metabolism of these pharmacologically important molecules and their expression patterns during development, which will help to determine the optimal growth conditions and harvest times for their production.

Index terms: early development, secondary metabolism, ecological functions, phenology.

\section{ALCALOIDES E ACETOGENINAS NO DESENVOLVIMENTO DE ANNONACEAE: CONSIDERAÇÕES BIOLÓGICAS}

RESUMO - Estudos químicos em plantas da família Annonaceae se intensificaram nas últimas décadas, devido à descoberta de moléculas de anonáceas com potencial medicinal (por exemplo, alcalóides benzilisoquinolina e acetogeninas). Aproximadamente 500 alcaloides têm sido identificados em 138 espécies de Annonaceae em 43 gêneros. Além disso, até 2004, 593 acetogeninas de annonaceas (ACGs) foram identificados, a partir de 51 espécies em 13 gêneros. Isto sugere que as plantas desta família atribuem recursos importantes para a biossíntese destes compostos. Apesar da diversidade destas moléculas, suas funções biológicas, incluindo as suas funções fisiológicas e/ou ecológicas, não são bem compreendidas. Neste estudo, foram fornecidos novos dados que descrevem a variedade e a distribuição de certos alcaloides e ACGs em annonaceas em fases distintas de desenvolvimento. As possíveis relações entre alguns destes compostos e as alterações climáticas sazonais ocorrendo no habitat são também discutidas. Estes dados vão melhorar a nossa compreensão do metabolismo secundário dessas moléculas farmacologicamente importantes e seus padrões de expressão durante o desenvolvimento, o que ajudará a determinar as condições ideais de crescimento e épocas de colheita para a sua produção.

Termos para indexação: desenvolvimento inicial, metabolismo secundário, funções ecológicas, fenologia.

\footnotetext{
${ }^{1}$ Palestra Anonáceas - V Congresso Internacional \& Encontro Brasileiro sobre Annonaceae: do gene à exportação (19 a 23 de Agosto de 2013). Botucatu-SP.

${ }^{2} \mathrm{Ph} . \mathrm{D}$, Researcher, Laboratorio de Fisiología y Química Vegetal, Facultad de Ciencias Biológicas, Universidad de Ciencias y Artes de Chiapas (UNICACH). Libramiento Norte Poniente 1150. Col. Lajas Maciel, CP. 29039, Tuxtla Gutiérrez, Chiapas, México. E-mail: aesquinca@unicach.mx.

${ }^{3} \mathrm{Ph} . \mathrm{D}$, Professor, Facultad de Ciencias Biológicas UNICACH, México. E-mail: ivan.cruz@unicach.mx

${ }^{4} \mathrm{Ph} . \mathrm{D}$, Professor, UNAM Prof., UNICACH, México. E-mail: marisol.castro@unicach.mx

${ }^{5}$ Postgraduate student UNAM, México. E-mail: orozcoagustin@hotmail.com.mx

${ }^{6}$ Postgraduate student UNAM Prof. UNICACH, México. E-mail: christian.riley@unicach.mx
} 


\section{The origin of the questions}

The Annonaceae is a family of plants widely distributed throughout tropical and subtropical regions and includes approximately 108 genera and 2400 species (CHATROU et al., 2012). This family is assigned to the clade Magnoliid according to the APG III system (2009) and according to Cronquist (1981) it was in subclass Magnoliidae, and order Magnoliales. It was among the first flowering plant families included in the ranalean complex, which is composed of families with older phenotypes. From a chemical perspective, the Annonaceae family has been considered a production centre for benzylisoquinoline alkaloids (CRONQUIST, 1981; WATERMAN, 1984).

The benzylisoquinoline alkaloids, specifically aporphinic alkaloids, are mainly produced by primitive plants of the Ranalean Complex (Table 1). In 2001, a sensu lato (registry of all aporphinic alkaloids) reported 801 aporphinic alkaloids (GONZÁLEZ-ESQUINCA, 2001). Members of the Annonaceae family produced $232(29 \%)$ of these alkaloids, while families in other orders produced 328 (41\%). Other families with abundant alkaloid production include the Lauraceae, with 116 reported alkaloids (14.5\%), and the Menispermaceae, with 108 (13.5\%). The great structural diversity of annonaceous alkaloids underscores the broad metabolic diversity in the Annonaceae family, as well as the importance of this family as a major producer of alkaloids (GONZÁLEZ-ESQUINCA, 2001). These many of these alkaloids have been reported as toxic, with effects on the mammalian central nervous system, including analgesic and narcotic properties (ALLEN et al., 2004 e ANKE et al., 2004) and antineoplastic, antiplatelet, dopaminergic, and antimicrobial activities (BERMEJO et al., 1995; YOU et al., 1995; WOO et al., 1997, 1999; CHANG et al., 1998; KUO et al., 2001; DE LACRUZ et al., 2011; LUNA CAZARES; GONZÁLEZ-ESQUINCA, 2008).

One of the most common oxoaporphine alkaloids is liriodenine, which is found in at least 86 genera and 240 Annonaceae species (GUINAUDEAU, LEBOEUF; CAVÉ, 1975, 1979, 1983, 1988, 1994; BENTLEY, 1997, 2001, 2002, 2003, 2004, 2005, 2006; GONZÁLEZ-ESQUINCA, 2001; DE LA CRUZ, 2012). This alkaloid is present in members of the Magnoliid clade (Canellales, Piperales, Laurales, and Magnoliales), with many representatives in the Magnoliales (143 Annonaceae and 35 Magnoliaceae species), as well as in phylogenetically distant Angiosperms (Alismatales,
Rosales, Sapindales, Malvales, and Gentianales). (Figure 1) (GONZÁLEZ-ESQUINCA, 2001; DE LA CRUZ; GONZÁLEZ-ESQUINCA, 2012). Liriodenine is also one of the few alkaloids produced by gymnosperms (XIE et al., 2011), this suggests that the alkaloid biosynthetic pathways in Annonaceae originated very early during evolution and it underscores the high conservation and diversification of the alkaloid biosynthetic genes among plants.

Similarly, a number of ACGs that are unique to the Annonaceae family have been reported. By 2004, 420 annonaceous acetogenins (ACGs) from 51 species and 13 genera were registered in the specialised literature (BERMEJO, 2005).

The ACGs, first described in 1982 by Jolard et al., are usually characterised by a long aliphatic chain of 35 to 37 carbon atoms bearing a terminal methylsubstituted $\alpha, \beta$-unsaturated $\gamma$-lactone ring, which is sometimes rearranged to produce a ketolactone with one, two, or three tetrahydrofuran (THF) rings, and several oxygenated moieties along the carbon chain. There are six main types of ACGs: linear ACGs that do not contain THF rings, epoxy-ACGs, mono-THF ACGs, bis-THF ACGs, tri-THF ACGs, and atypical ACGs with a tetrahydropyran (THP) ring. The lactone ring may be unsaturated, substituted, or rearranged as a ketolactone (CAVE et al., 1997). These natural compounds are of particular interest because of their antitumoral, cytotoxic, antiparasitic, insecticidal, antifungal, and immunosuppressive activities. ACG biosynthetic intermediates resemble the metabolites of very primitive organisms, suggesting an ancient origin for this family.

The diversity of alkaloids and ACGs in the Annonaceae family suggests that these secondary metabolites may provide an evolutionary advantage. The persistent biosynthesis of these products appears to indicate a role for these compounds in physiological, ecological, and/or evolutionary functions that are important for survival of the plants in this family.

The ACGs appear to be metabolites specific to the Annonaceae family. Therefore, their biosynthetic pathways are expected to have originated in this plant family. On the other hand, the Annonaceae species have made a major contribution to alkaloid diversity. Because different Annonaceae species have distinct physiological and phenological characteristics, the ecological significance of these compounds is likely to be broad.

The diversity of ACGs and alkaloids found in Annonaceae implies that these plants dedicate photosynthetic resources to this biosynthesis and also implies the conservation of a genetic program 
between species. Therefore, the biosynthesis of these molecules is important for the plants producing them. However, the specific roles of these molecules remain unclear. Diverse strategies must therefore be implemented to dissect the function of these metabolites. A first approach involves the determination of their distributions within the plant. Where in the plant are these compounds synthesised? Is there a specific period in the phenological cycle that is especially crucial for their biosynthesis? Are these biosynthetic pathways constitutively active, or are they induced by specific biotic or abiotic factors? What are their ecological and/or physiological roles? These questions reflect the limitations of our knowledge of the biology of these compounds and suggest lines of investigation for future research.

\section{In search of answers}

Among the most abundant species of wild or semi-wild Annona from the tropical caducifolia rainforest in the central depression of the Chiapas State, Mexico, are A. diversifolia, A. lutescens, and A. purpurea, and A. muricata is an abundant crop species. These trees produce edible fruit, and they are typically exposed to well-demarcated periods of rain or drought and are therefore subjected to changing environmental conditions (Figure 2). The variations in their phenological and physiological cycles are among the most important differences between the species. For example, the fruiting of $A$. diversifolia and $A$. purpurea peaks at the end of rainy periods (i.e., during drought periods), and their seeds have a hard seed coat and long latency. In contrast, A. lutescens bear fruits at the end of the drought season, and their seeds have a soft coat and do not show latency. A. muricata exhibit yet another pattern, fructifying (although to different extents) throughout the whole year, and its seeds do not show latency. In this study, it was used the above mentioned species as models for the study of the secondary metabolism of alkaloids and ACGs.

Isolated compounds such as liriodenine alkaloids (GONZÁLEZ-ESQUINCA, 2001), atherospermidine and lisicamine from $A$. diversifolia: oxopurpureine and annomontine from Annona purpurea (GONZÁLEZ-ESQUINCA, 2001; REJÓN-ORANTES et al., 2011) (Figure 3), and the ACGs laherradurine, rolliniastatin-1, rolliniastatin-2, and cherimolin-2 from Annona diversifolia and A. lutescens (Figure 3) (DE LA CRUZ, 2001, ABRAJAN, 2002; SCHLIE-GUZMÁN et al., 2009, LUNA-CAZARES; GONZÁLEZ-ESQUINCA, 2010) are found in different organs of the plants, and their distinct localizations have shed light on the functions that these types of molecules may play in the plants that produce them.

\section{Organ-specific variation associated with species ontogeny}

The biosynthesis and accumulation of secondary metabolites is commonly associated with plant development (GREGIANINI et al., 2004; BOEGE, 2005; PARRA-GARCÉS et al., 2010; CAROPRESE et al., 2011). Both alkaloids and ACGs were constitutively expressed in the Annona species that were studied, but they were found in different organs and distinct developmental stages.

It has been established, for example, that certain alkaloids are produced during the early developmental stages of $A$. diversifolia, A. lutescens, A. muricata, and A. purpurea. Among our most significant observations, it was found that alkaloids are not synthesised during seed organogenesis, their biosynthesis begins very early during germination (Figure 4), and the chemical profile of each organ is enriched as the seedling completes its development. Variation in the concentration and number of alkaloids in each organ of the seedling is common. Some alkaloids depend only on the reserve mobilisation from endosperm, while others are only synthesised when the seedling becomes photosynthetic. The alkaloid profile from seedlings with six leaves (approximately 60 days after germination) is similar to the alkaloid profile in the adult plant, at least in the case of $A$. diversifolia (Figure 5) (DE LA CRUZ; GONZÁLEZ-ESQUINCA, 2012, DE LA CRUZ, 2012; ALFARO 2005, CONTRERAS, 2010). In A. diversifolia and A. lutescens, the emergence of the primary root is accompanied by the initiation of liriodenine alkaloid biosynthesis. This compound is detected first in the endosperm, where it persists until the seedling stage, and then in other organs as they begin the differentiation process. The differentiation of the hypocotyl and epicotyl in A. diversifolia, the species that has been best characterised during early development, is accompanied by the production of two additional alkaloids, lisicamine and atherospermidine. The biosynthesis of these three alkaloids in specific stages of development appears to be linked to the degradation of stored proteins (Figure 6) (DE LA CRUZ; GONZÁLEZ-ESQUINCA, 2012, DE LA CRUZ, 2012). The allocation of stored resources for the biosynthesis of these alkaloids suggests that their functions are important for specific stages of development. 
The seedlings and adults from the four Annona species mentioned above have similar organspecific alkaloid profiles (e.g., the alkaloids are more prevalent in the roots). However, the presence of alkaloids has been documented throughout the whole phenological cycle. For example, in A. lutescens, once the biosynthesis of liriodenine is initiated, this compound can be detected in seedlings and juveniles, as well as throughout the complete annual cycle of the adult plant (Figura 7). However, there are relevant differences in the quantity of this molecule between distinct stages and organs (CASTRO-MORENO et al., 2013). Similar to liriodenine, other alkaloids are present throughout the complete phenological cycle of at least four Annona species. This implies a continuous allocation of resources and energy to their biosynthesis, transport, and accumulation.

\section{Ecological and physiological variation}

The characteristic and dramatic changes between the drought and rainy seasons in the Tropical Deciduous Forest suggest additional ecological implications for the production of alkaloids by plants such as $A$. diversifolia and A. lutescens. These environmental changes induce phenological and physiological changes that are also regulated by the genetic program of the plant. It was recorded an exponential increase in the liriodenine content of the roots during the most severe stage of the drought season (Figure 8) (CASTRO-MORENO et al., 2013). During this time, the plants lose their leaves for several different reasons, including the recycling of nutrients during senescence and foliar death processes. The liriodenine in the roots appears to play a role in the development of resistance to drought conditions.

Another potential function of liriodenine is nitrogen storage; the seedlings respond to the availability of nitrogen by accumulating nutrients, mainly in the roots. The biomass production ratio of alkaloids indicates that the production of alkaloids is inversely proportional to the biomass and that nitrogen availability seems to compensate for this effect (Figure 9) (OROZCO, 2009). These data suggest that liriodenine could have more than one function.lutescens Safford during drought and rainy season.

Another important secondary metabolite production pathway is the biosynthesis of ACGs (CAVE et al., 1997; ALALI, 1999; BERMEJO, 2005), which differs from alkaloid biosynthesis and seems to take place in the plant embryo during embryogenesis. For this reason, it may be possible to isolate ACGs from the seeds of all members of this plant family. ACGs are found in many parts of the plant, while alkaloids are generally not present in the leaves or seeds. The genetic activation of these pathways (alkaloid vs. ACGs biosynthesis) is organ specific. For example, when $A$. lutescens fructify, the majority of alkaloids (liriodenine) are accumulated in the roots, while the ACGs laherradurine, rolliniastatin-2, and iso-anno-reticuline are accumulated in the seeds and roots (ABRAJAN, 2002).

\section{Significance}

The presence of liriodenine during early plant development and the serendipitous finding that the seeds of Annona species can be contaminated with Rhizopus stolonifer and Aspergillus glaucus fungi only during the first days of imbibition (these contaminants disappear when the radicle is visible) allowed the evaluation of the antifungal activity of liriodenine in A. diversifolia. In vitro studies demonstrated that liriodenine completely inhibited the proliferation of both fungi with minimal inhibitory concentrations of $200 \mu \mathrm{M}$ and $100 \mu \mathrm{M}$, respectively (DE LA CRUZ et al., 2011). In vivo, this alkaloid can also inhibit at least 23 other phytopathogenic fungi, including Puccinia graminis, Phytophthora infestans, and Helminthosporium teres (HUFFORD et al., 1980). The amounts of liriodenine detected per milligram of tissue are 10 to 100,000 -fold larger that the minimal inhibitory concentrations needed, allowing the plant to counteract multiple fungal invasions (Table 2). The early development of $A$. diversifolia is accompanied by the exponential accumulation of liriodenine in all tissues. Concomitantly, a gradual reduction in phytopathogens is observed. This suggests that the seed allocates a portion of its stored resources for the production of antimicrobial substances and implicates liriodenine in an early defence mechanism against phytopathogens as a survival strategy in this species (DE LA CRUZ et al., 2011).

The distribution of ACGs during the early stages of development also supports an important role for secondary metabolites in the Annonaceae. The ACGs laherradurine and rollinstatine-2 are distributed throughout all organs of $A$. muricata seedlings. Rollinstatine-2 is more abundant than laherradurine, except in the leaves (Figure 10). Significant amounts of these ACGs are expressed in the roots and leaves during several developmental stages. The plant seems to produce more rollinstatine- 2 in the roots than in the leaves (with a 2-fold greater expression in the roots in 2-leaf seedlings and 26-fold greater 
expression in 6-leaf seedlings). In contrast, more laherradurine is produced in the leaves (40-fold greater expression in the leaves of 2-leaf seedlings). These differences in ACG concentrations could have multiple explanations: 1) one of the ACGs is more potent, e.g., Coloma et al., 2002 reported that laherradurine had greater activity against Spodoptera littoralis (phytophagous plague) larvae than did rollinstatin-2 (86\% and $29.7 \%$ mortality, respectively);2) the plant allocates greater resources to the protection of the leaves because of their photosynthetic function and to protect the roots because of their important nutrient and water transport functions (i.e., roots and leaves should be considered equally valuable to the plant) (KAPLAN et al., 2008); and 3) these ACGs could have specific activities against distinct groups of pathogens. For example, $100 \mu \mathrm{g} / \mathrm{disk}$ of rollinstatin-2 but not laherradurine inhibits Candida albicans (although this fungus is not a phytopathogen), producing an inhibition halo of $15 \mathrm{~mm}$ in diameter (RILEY, 2007). These explanations are consistent with the optimal defence theory (MCKEY, 1974), which predicts that because defence mechanisms are expensive for the plant, they should be allocated to the most valuable organs, in this case, the leaves and roots.

The changes observed in these two ACGs during ontogeny, germination, and seedling development may represent a defence strategy that is dependent on the developmental stage and independent of biotic or abiotic factors, with plasticity to permit modulation in the presence of adverse factors. The early developmental model and secondary metabolism of alkaloids and ACGs in Annonaceae provide an opportunity to evaluate distinct plant defence theories (BERENBAUM 1995; ESPINOSA-GARCÍA, 2001; STAMP, 2003). The current theories do not incorporate the impact of early plant development.

Current evidence from Annonaceae support the optimal defence theory (OD) (STAMP, 2003; LANGEHEIM, 2001) and the growth-differentiation balance (GDB) hypothesis. The latter underscores the physiological trade-offs between growth, differentiation, and secondary metabolite production (HERMS; MATTSON, 1992).

\section{Exploration of future opportunities based on current findings: questions}

What are the relationships among alkaloid and ACGs biosynthesis, the stage of plant development or specialisation, and environmental factors?; What is the ecological or physiological significance of alkaloids and ACGs for the plants that produce them?; Why are these compounds produced mostly in Annonaceae?

The exploration of alkaloid dynamics and ACG accumulation in the different tissues of plants that live in changing environments will provide important contributions to our understanding of the physiological and ecological responses of these species. 


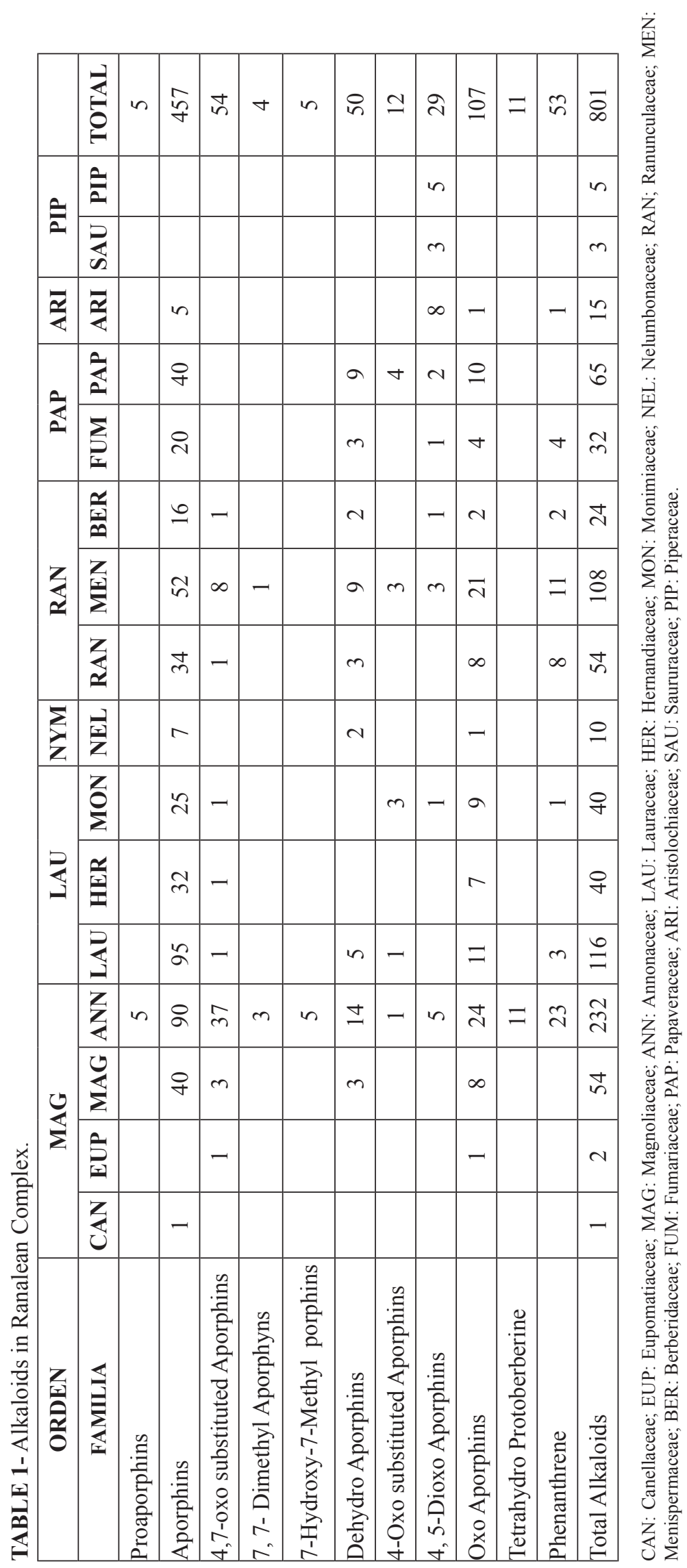




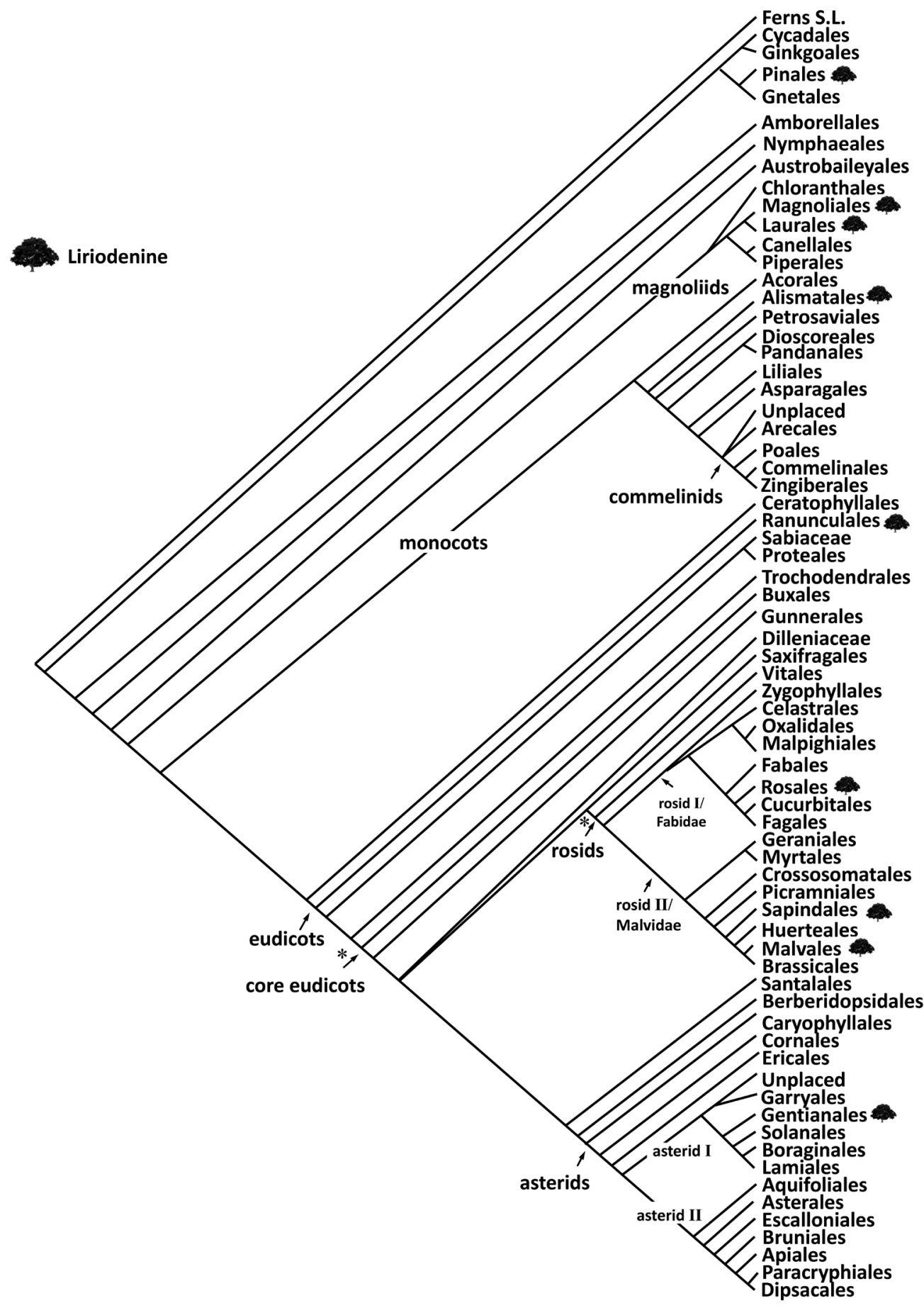

FIGURE 1- Phylogenetic distribution of alkaloid liriodenine. 
TABLE 2- Comparison between liriodenine content in tissues and antifungal activity.

\begin{tabular}{|c|c|c|c|}
\hline \multicolumn{2}{|c|}{ Liriodenine content in tissues from Annonaceae } & \multicolumn{2}{|c|}{ Liriodenine activity over phytopathogens } \\
\hline Specie/Tissue & $\mu \mathrm{mol} / \mathrm{g}$ dried plant & Fungi & $\mathrm{CI} \mu \mathrm{mol} / \mathrm{mL}$ \\
\hline $\begin{array}{l}\text { A. lutescens }{ }^{1} \\
\text { Root } 2 \text { year-young plant } \\
\text { Root mature plant }\end{array}$ & $\begin{array}{l}775 \\
378\end{array}$ & Aspergillus fumigatus ${ }^{9}$ & 0.09 \\
\hline $\begin{array}{l}\text { A. diversifolia }{ }^{2} \\
\text { root seedling with two leaves } \\
\text { root seedling with six leaves }\end{array}$ & $\begin{array}{l}1.50 \\
2.83\end{array}$ & Laetiporus sulphureus ${ }^{10}$ & 0.007 \\
\hline $\begin{array}{l}\text { Mitrephora glabra }{ }^{3} \\
\text { stem bark mature plant }\end{array}$ & 0.04 & Lenzites betulina ${ }^{10}$ & 0.003 \\
\hline $\begin{array}{l}\text { Rollinia mucosa }{ }^{4} \\
\text { leaves mature plant }\end{array}$ & 0.04 & Trametes versicolor ${ }^{11}$ & 0.01 \\
\hline $\begin{array}{l}\text { Fissistigma latifolium } \\
\text { stem bark mature plant }\end{array}$ & 0.06 & Aspergillus glaucus ${ }^{12}$ & 0.1 \\
\hline $\begin{array}{l}\text { Rollinia leptopetala }{ }^{6} \\
\text { root bark mature plant }\end{array}$ & 0.46 & Rhizopus stolonifer ${ }^{12}$ & 0.2 \\
\hline $\begin{array}{l}\text { A. reticulata }{ }^{7} \\
\text { root bark mature plant }\end{array}$ & 0.18 & Botrytis faba ${ }^{9}$ & 0.14 \\
\hline $\begin{array}{l}\text { Mollinedia glaziovii }{ }^{8} \\
\text { stem bark in fruiting plant }\end{array}$ & 735 & $\begin{array}{l}\text { Syncephalastrum } \\
\text { racemosum }^{9}\end{array}$ & 0.01 \\
\hline $\begin{array}{l}\text { M. } \text { gigliana }^{8} \\
\text { stem bark in vegetative plant }\end{array}$ & 249 & Pyricularia oryzae $e^{11}$ & 0.14 \\
\hline
\end{tabular}

References: ${ }^{1}$ Castro-Moreno et al., 2013; ${ }^{2} \mathrm{De}$ la Cruz y González-Esquinca, 2012; ${ }^{3} \mathrm{Li}$ et al., 2009; ${ }^{4} \mathrm{De}$ Lima et al., $2012 ;{ }^{5} \mathrm{Alias}$ et

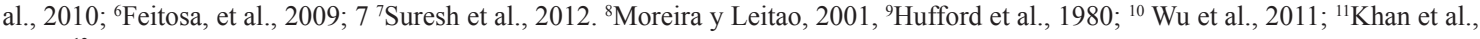
2002; ${ }^{12}$ De la Cruz et al., 2011.

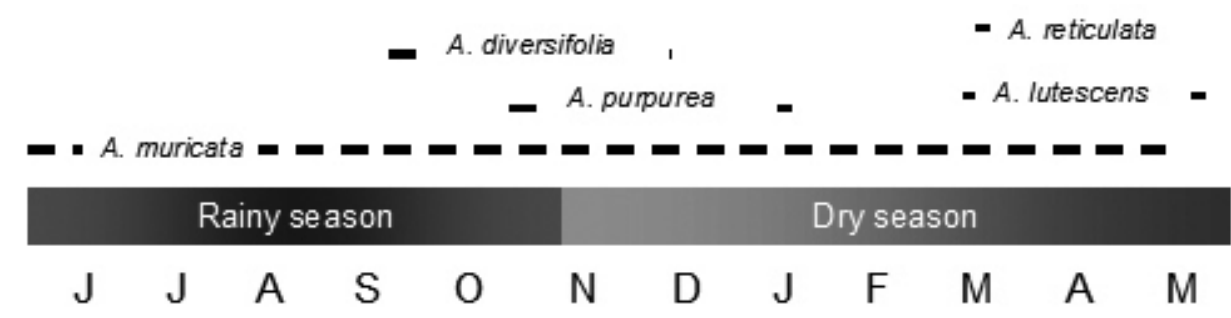

FIGURE 2- Phenology of Annona species. 


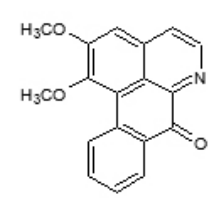

Lisicamine<smiles>Nc1nccc(-c2nccc3c2[nH]c2ccccc23)n1</smiles>

Annomontine

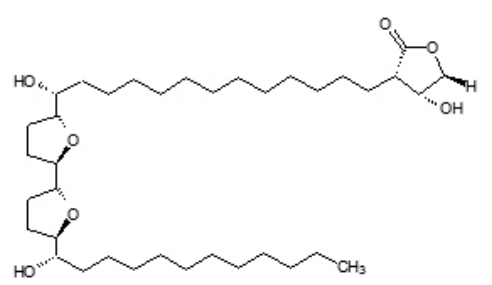

Laherradurin<smiles>O=C1c2ccccc2-c2c3c(cc4ccnc1c24)OCO3</smiles>

Liriodenine

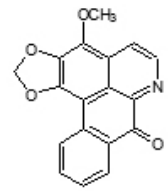

Atherospermidine<smiles></smiles>

Oxopurpureine

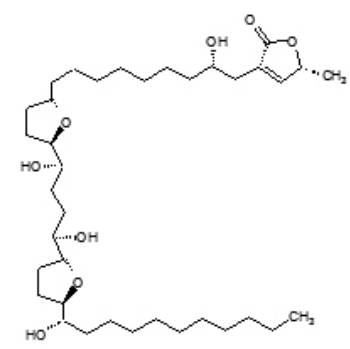

Cherimoline-2

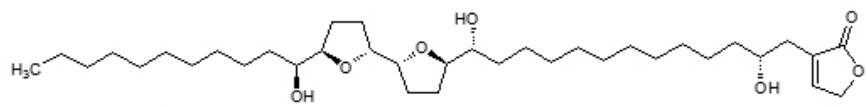

Rolliniastatin-2

FIGURE 3- Alkaloids and acetogenins isolated from Annona species.

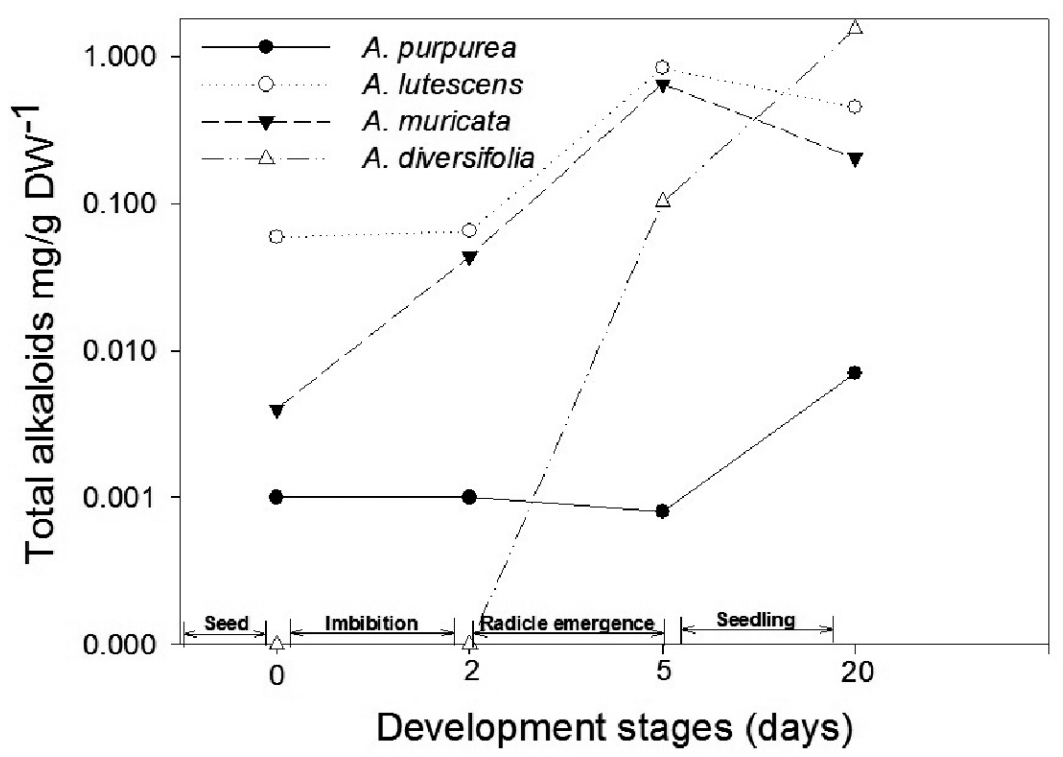

FIGURE 4- Alkaloids biosynthesis during early development in Annona species. 

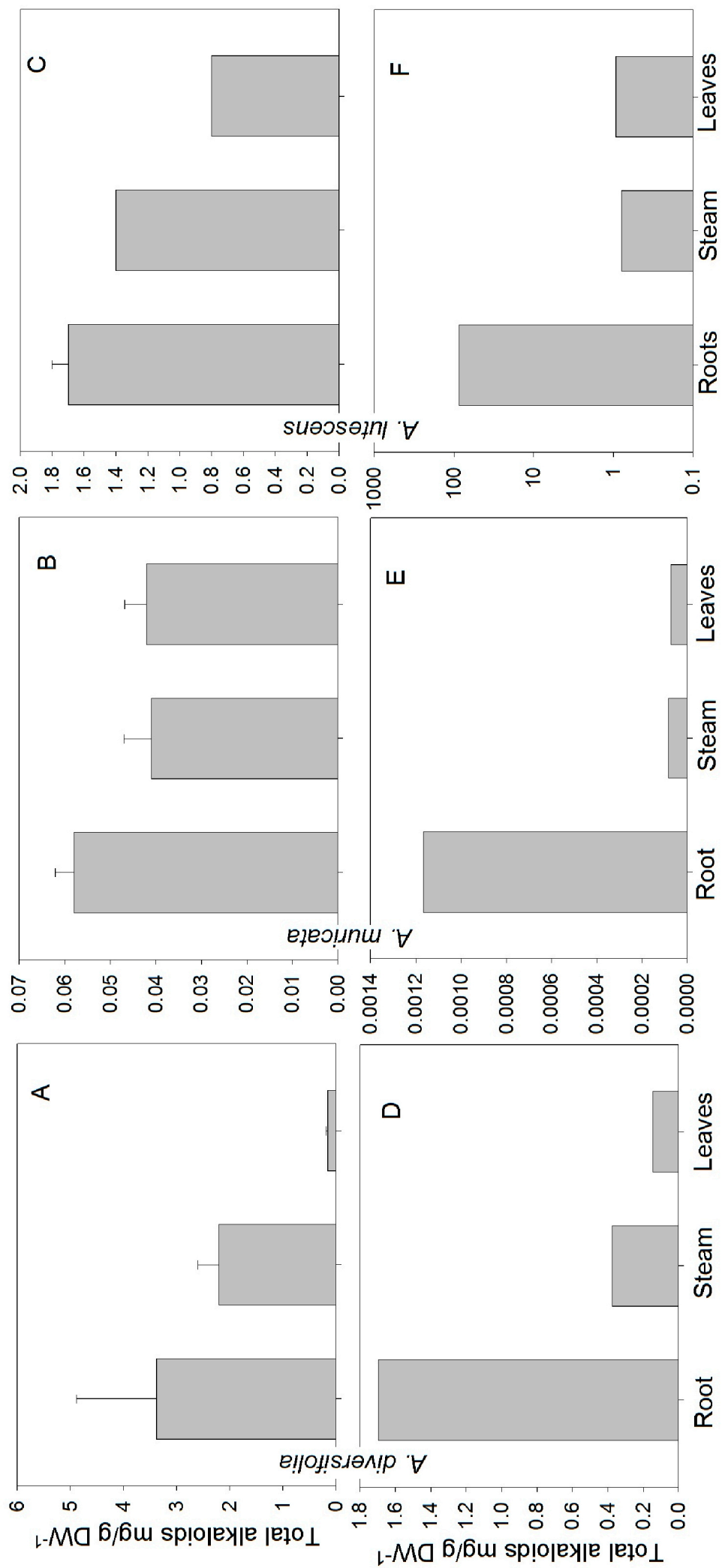

FIGURE 5- Alkaloids accumulation in seedlings and adults plants of Annona diversifolia, Annona muricata and Annona lutescens. Seedlings (A, B and C) and adults plants (D, E y F). 


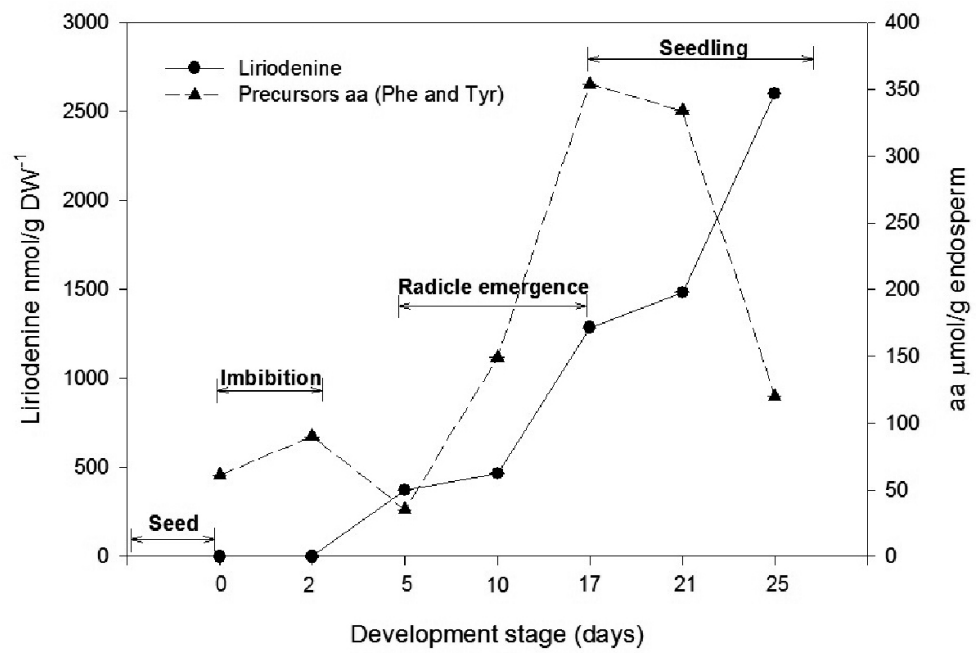

FIGURE 6 - Metabolic relation between reserve mobilization and the liriodenine alkaloid biosynthesis in early development Annona diversifolia Safford.

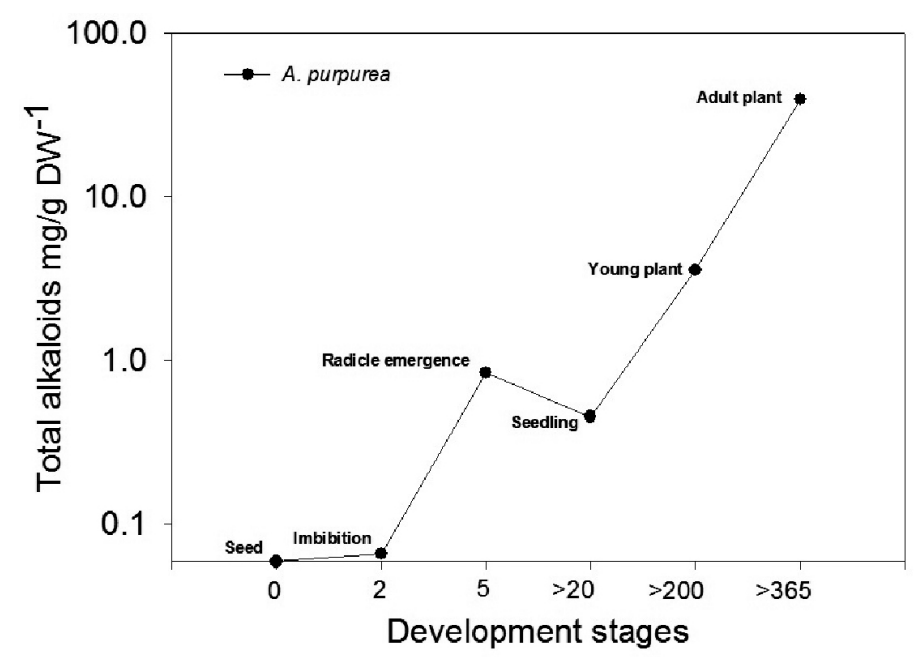

FIGURE 7- Ontogenetic accumulation of alkaloids in Annona lutescens Safford.

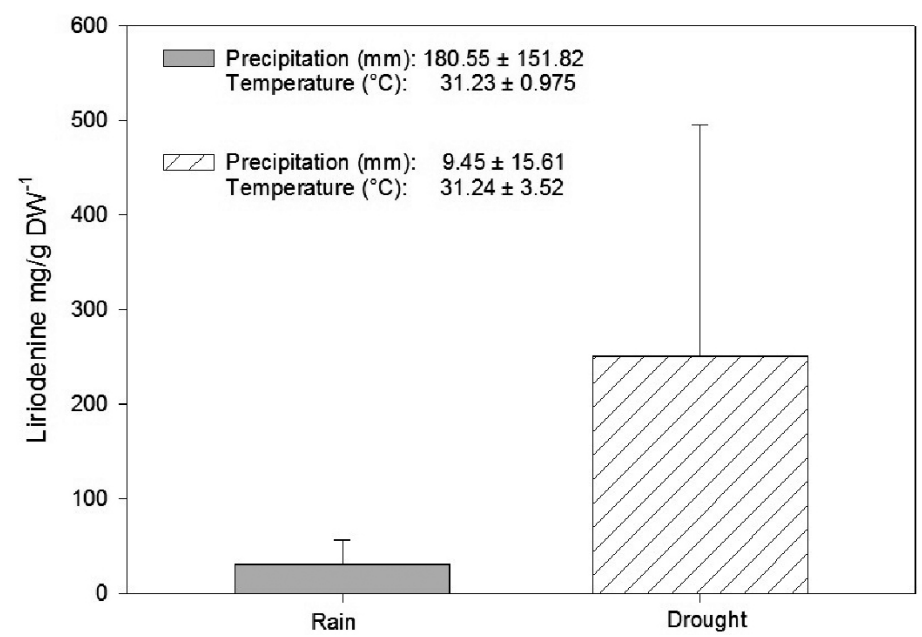

FIGURE 8- Liriodenine alkaloid in Annona lutescens Safford during drought and rainy season. 
(6) $+46 !$

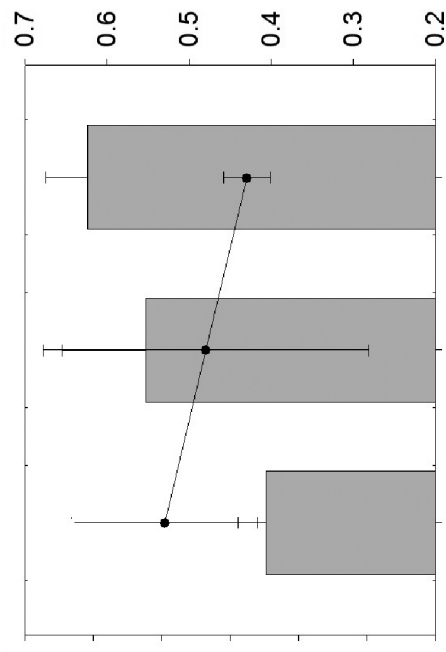

\&

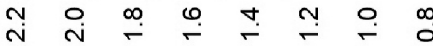

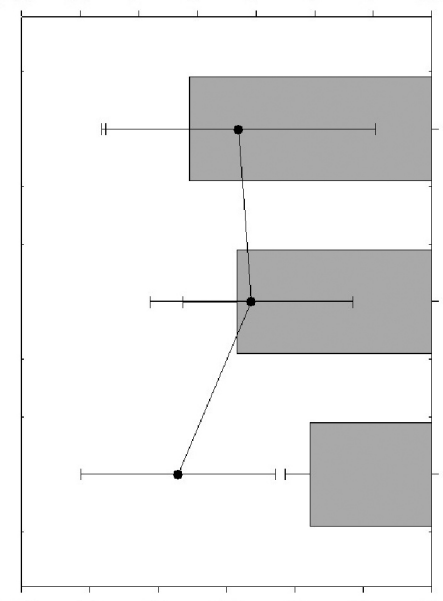

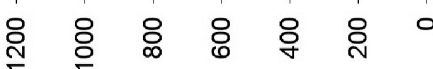

గิ㇒冋

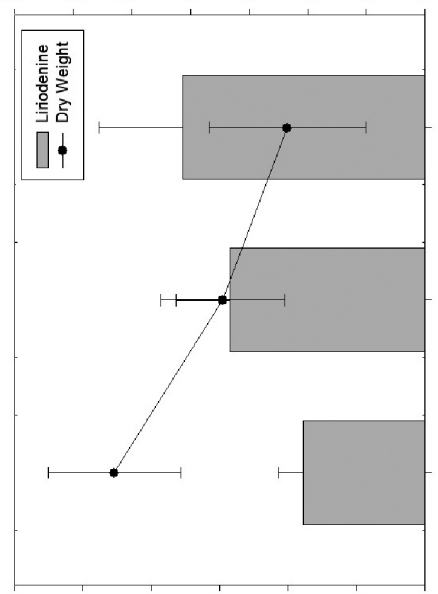

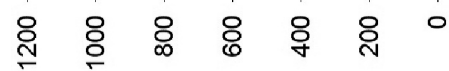

„.Ma 6/6u әu! иәро!!?

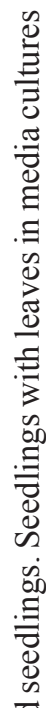

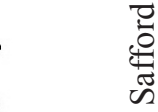

$\stackrel{8}{\pi}$

$\begin{array}{ll}z & 0 \\ \sum & 0 \\ \text { z } & 0 \\ 8 & 0 \\ 8 & \vdots \\ 8 & \vdots\end{array}$

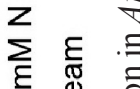

$8 \stackrel{0}{0}$

$\sum_{E}^{z}$

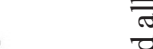

.ำ.

$z \quad \frac{0}{0}$

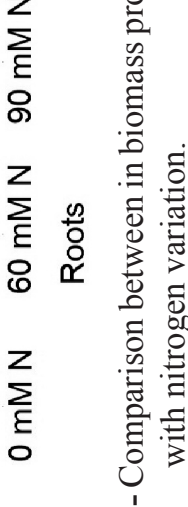

일

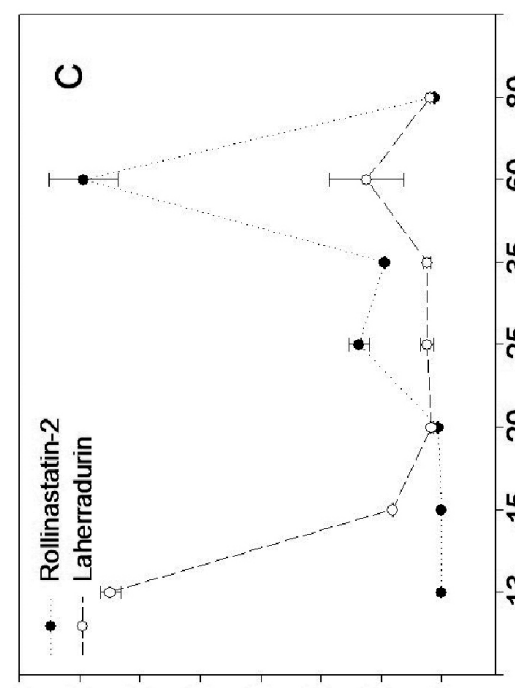

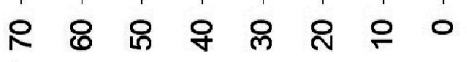

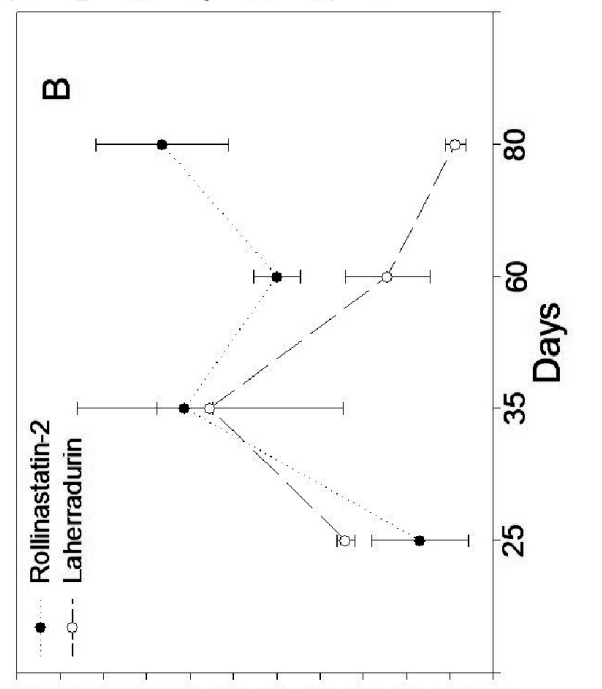

แัปกำ

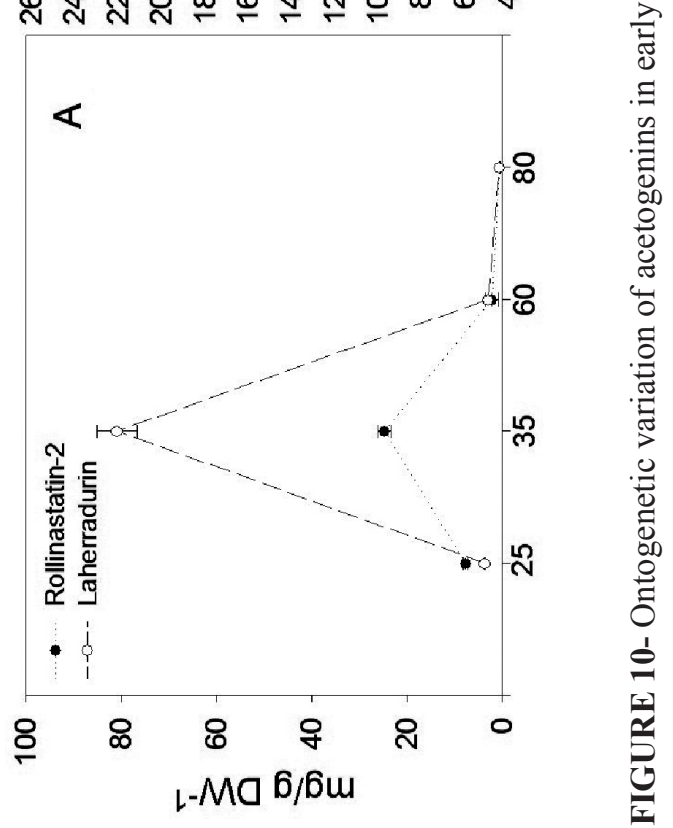




\section{REFERENCES}

ABRAJÁN HERNANDEZ, P. Acetogeninas y compuestos de Annona lutescens Safford. 2002. 75f. Tesis (Licenciatura en Ingeniería Química)Instituto Tecnológico de Tuxtla Gutiérrez. Tuxtla Gutiérrez. 2002.

ALALI F. Q.; LIU X. X.; MCLAUGHLIN J. L. Annonaceous acetogenins: recent progress. Journal of Natural Products, Cincinnati, v 62, p.504-540, 1999.

Alfaro ROMERo, T.J. Producción de acetogeninas y alcaloides durante la germinación y primeras etapas del desarrollo de Annona lustescens Saff. (Annonaceae). 2005. 73 f. Tesis (Licenciatura en Biología)- Universidad de Ciencias y Artes de Chiapas, Tuxtla Gutiérrez, 2005.

ALIAS. A.; HAZNI, H.; JAAFAR, F.M.; AWANG, K.; ISMAIL, N.H. Alkaloids from Fissistigma latifolium (Dunal) Merr. Molecules, Moscow, v.15, n. 7, 4583-4588, 2010.

ALLEN R. S.; MILLGATE A. G.; CHITTY J. A.;THISLETON J.; MILLER J. A.C.; FIST A. J.; GERLACH W.L.; LARKIN P. J. RNAi-mediated replacement of morphine with the nonnarcotic alkaloid reticuline in opium poppy. Nature Biotechnology, New York, v. 22, p.1559-1566, 2004.

ANKE, S.; NIEMÜLLER, D.; MOLL, S.; HÄNSCH, R.; OBER, D. Polyphyletic Origin of pyrrolizidine alkaloids within the Asteraceae. Evidence from differential tissue expression of homospermidine synthase. Plant physiology, Rockville, v.136, p. 4037- 4047, 2004.

APG III - The Angiosperm Phylogeny Group. An update of the angiosperm phylogeny group classification for the orders and families of flowering plants. APG III. Botanical Journal of the Linnean Society, Londres, v.161, p. 105-121, 2009.

BENTLEY, K.W. $\beta$-Phenylethylamines and the isoquinoline alkaloids. Natural Product Reports, London, v.14, p.387-411, 1997.

BENTLEY, K.W. $\beta$-Phenylethylamines and the isoquinoline alkaloids. Natural Product Reports, London, v.18, p.148-170, 2001.
BENTLEY, K.W. $\beta$-Phenylethylamines and the isoquinoline alkaloids. Natural Product Reports, London, v.19, p.332-356, 2002.

BENTLEY, K.W. $\beta$-Phenylethylamines and the isoquinoline alkaloids. Natural Product Reports, London, v.20, p.342-365, 2003.

BENTLEY, K.W. $\beta$-Phenylethylamines and the isoquinoline alkaloids. Natural Product Reports, London, v.19, p.332-356, 2004.

BENTLEY, K.W. $\beta$-Phenylethylamines and the isoquinoline alkaloids. Natural Product Reports, London, v.22, p.249-268, 2005.

BENTLEY, K.W. $\beta$-Phenylethylamines and the isoquinoline alkaloids. Natural Product Reports, London, v 23, p.444-463, 2006.

BERENBAUM M.R. The chemistry of defense: theory and practice. Proceedings of the National Academy of Sciences USA, Washington, v 92, p.2-8, 1995.

BERMEJO, A.; FIGADERA, B.; ZAFRA-POLO, M.C.; BARRACHINA, I.; ESTORNELL, E.; CORTES, D. Acetogenins from annonaceae: recent progress in isolation, synthesis and mechanisms of action. Natural Product Report, London, v.22, p.269-303, 2005.

BERMEJO, A.; PORTÁIS, P.; BLÁZQUEZ, M.A.; RAO, S.K.; ZAFRA-POLO, M.C.; CORTES, D. Dopaminergic isoquinoline alkaloids from roots of Xilopia papuana. Natural Product Letters, England, v.6, p.57-6, 1995.

BOEGE, K. Influence of plant ontogeny on compensation to leaf damage. American Journal of Botany, St. Louis, MO, v.92, p. 1632-1640. 2005.

CAROPRESE, A. J.; PARRA, G. M.; ARRIETA, P. D.; STASHENKO, E. Microscopic anatomy and volatile secondary metabolites at three stages of development of the inflorescences of Lantana camara (Verbenaceae). Revista de Biología Tropical, San José, CR v. 59 n.1, 473-486. 2011.

CASTRO-MORENO, M.; TINOCO-OJANGUREN, L. C.; CRUZ-ORTEGA, M. R.; GONZÁLEZESQUINCA, A. R. Influence of seasonal variation on the phenology and liriodenine content of Annonalutescens (Annonaceae) Journal of Plant Research, Tokyo, v.124, n.4, p.529-537, 2013. 
CAVÉ, A.; FIGADÉRE, B.; LAURENS, A.; CORTES, D. Acetogenins from Annonaceae. Progress in the Chemistry of Organic Natural Products, Vienna, v.70, p.81-288, 1997.

CHANG, F.R.; WEI, J.L.; TENG, C.H. M.; WU, Y. CH.; Two new 7 dehidroaporphine alkaloids and antiplateleted action aporphines from the leaves of Annona purpurea. Phytochemistry Pergamon, Philadelphia, v.49, n.7, p.2015-2018, 1998.

CHATROU, L.W.; PIRIE, M.D.; ERKENS, R.H.J.; COUVREUR, T.L.P.; NEUBIG, K.M.; ABBOTT, J.R.; MOLS, J.B.; MAAS, J.W.; SAUNDERS, R.M.K.; CHASE, M.W. A new subfamilial and tribal classification of the pantropical flowering plant family Annonaceae informed by molecular phylogenetics. Botanical Journal of the Linnean Society, London, v 169, p.5-40, 2012.

CONTRERAS COUTIÑO, T. E. Annona muricata L. (ANNONACEAE): Acetogeninas y Alcaloides en etapas tempranas de desarrollo. 2010. $73 \mathrm{f}$. Tesis (Licenciatura en Biología)- Universidad de Ciencias y Artes de Chiapas, Tuxtla Gutiérrez, 2010.

CRONQUIST A. An integrated system of classification of flowering plants. New York: Columbia University Press, 1981. 1262 p.

DE LA CRUZ CHACÓN, I. Acetogeninas Bioactivas de Annona diversifolia Safford. 2001. 91 f. Tesis (Licenciado en Ingeniería Bioquímica)Instituto Tecnológico de Tuxtla Gutiérrez, Tuxtla Gutiérrez, 2001.

DE LA CRUZ CHACÓN I. Alcaloides bencilisoquinolínicos y su relación órgano-específica en las primeras fases de desarrollo de Annona diversifolia safford. 2012. $171 \mathrm{f}$. Tesis (Doctorado en Ciencias Biológicas)- Universidad Nacional Autónoma de México, México, 2012

DE LA CRUZ CHACÓN I.; GONZÁLEZESQUINCA A.R. Liriodenine alkaloid in Annona diversifolia during early development. Natural Product Research, Milton Park, UK v.26, n.1, p.42-49, 2012.

DE LA CRUZ CHACÓN, I.; GONZÁLEZESQUINCA, A.R.; GUEVARA FEFER, P.; JIMÉNEZ GARCÍA, L.F. Liriodenine, early antimicrobial defense in Annona diversifolia. 2011.
Zeitschrift für Naturforschung C. A Journal of Biosciences, Tübingen, v.66, n.7, p.377-384, 2011

DE LIMA, JP. S. et al. In vitro antileishmanial and cytotoxic activities of Annona mucosa (Annonaceae). Revista Virtual de Química, Rio de Janeiro, v.4, n. 6, p.692-702,. 2012.

ESPINOSA-GARCÍA, F.J. La diversidad de los metabolitos secundarios y la teoría de la defensa vegetal. In: ANAYA, A.L.; ESPINOSA-GARCÍA, F.; CRUZ-ORTEGA, R. Relaciones químicas entre organismos: aspectos básicos y perspectivas de su aplicación. Plaza y Valdes, México, v.6, p. 231250, 2001.

FEITOSA, E.M.A. et al . Chemical composition and larvicidal activity of Rollinia leptopetala (Annonaceae). Journal of the Brazilian Chemical Society, São Paulo, v.20, n. 2, p.375-378, 2009.

GONZÁLEZ-COLOMA A.; GUADAÑO A; DE INÉS C, D.; MARTÍNEZ-DÍAZ R.; CORTES D. Selective action of acetogenin mitochondrial complex I inhibitors. Z. Naturforsch C, Tübingen, v. 57 p. $1028-1034.2002$.

GONZÁlEZ ESQUINCA, A. R. Contribución al Estudio del Género Annona (Annonaceae), Análisis Fitoquímico de Tres Especies del Estado de Chiapas. 2001. $251 \mathrm{f}$. Tesis (Doctorado en Ciencias Biológicas)- Universidad Nacional Autónoma de México, México, 2001.

GREGIANINI, T, S.; PORTO, D, D.; DO NASCIMENTO, N, C.; FETT, J. P.; HENRIQUES, A. T.; FETT-NETO, A. G. Environmental and ontogenetic control of accumulation of brachycerine, a bioactive indole alkaloid from Psychotria brachyceras. Journal of Chemical Ecology, New York, v.30, p. 2023-2036. 2004.

GUINAUDEAU, H.; LEBOEU,F M.; CAVÊ, A. Aporphinoid alkaloids V. Journal of Natural Products, Washington, v.57,n 8, p.1033-1135, 1994.

GUINAUDEAU, H.; LEBOEUF, M.; CAVÉ, A. Aporphinoid Alkaloids IV. Journal of Natural Products, Washington, v.51, n 3, p. 389-474, 1988.

GUINAUDEAU, H.; LEBOEUF, M.; CAVÉ, A. Aporphine Alkaloids II. Journal of Natural Products, Columbus, v.42, n.4, p.325-360, 1979.14 15 ALKALOIDS AND ACETOGENINS IN 
ANNONACEAE DEVELOPMENT... v. 36, edição especial, e., p. 001-016, Janeiro 2014.

GUINAUDEAU, H.; LEBOEUF, M.; CAVÉ, A. Aporphinoid Alkaloids III. Journal of Natural Products, Columbus, v.46, n.6, p.761-835, 1983.

GUINAUDEAU, H.; LEBOEUF, M.; CAVÉ, A. Aporphine Alkaloids. Lloydia. Columbus, v.38, n. 4, p.275, 305, 309, 1975.

HERMS, D. A.; MATTSON, W. J. The dilemma of plants: to grow or defend. Quarterly Review of Biology, Chicago, USA p. 283-335. 1992.

HUFFORD, C. D.; SHARMA, A.S.; OGUNTIMEIN, B.O. Antibacterial and antifungal activity of liriodenine and related oxoaporphine alkaloids. Journal Pharmaceutical Science, Lawrence, v.69, n.10, p.1180-1183, 1980.

KAPLAN, I.; HALITSCHKE, R.; KESSLER, A.; SARDANELL,I S.; DENNO, R. F. Constitutive and induced defenses to herbivory in above- and belowground plant tissues. Ecology, Washington, v.89, n.2, p.392-406, 2008.

KHAN, M.R.; KIHARA, M.; OMOLOSO, A.D. Antimicrobial activity of Michelia champaca. Fitoterapia, Milan, v.73, p.744-748, 2002.

KUO, R. Y.; CHANG, F.R.; CHEN, CH.; YEN, H.F.; WO, Y.CH. Antiplatelet activity of N-methocycarbonyl aporphines from Rollinia mucosa. Phytochemistry, Amsterdam, v.57, p.421425, 2001

LANGENHEIM, J. H. Contribuciones de los estudios de largo plazo a la teoría de la defensa química: perspectivas con árboles resinosos de zonas templadas y tropicales. In: ANAYA, A.L.; ESPINOSA-GARCÍA, F.; CRUZ-ORTEGA, R. Relaciones químicas entre organismos: aspectos básicos y perspectivas de su aplicación. Plaza y Valdes, México, p. 251-304, 2001.

LEBOEUF, M.; CAVÉ, A., BHAUMIK, K.; MUKHERERJEE, B.; MUKHERERJEE, R. The phytochemistry of Annonaceae. Phytochemistry, Amsterdam, v.21, n.12, p.2783-2813, 1982.

LI, C.; LEE, D.; GRAF, T.N.; PHIFER, S.S.; NAKANISHI. Y.; RISWAN. S.; SETYOWATI. F.M.; SARIBI, A.M.; SOEJARTO. D.D,. FARNSWORTH,
N.R.; FALKINHAM，J.O.; KROLL, D.J.; KINGHORN, D.; WANI, M.C.; OBERLIES, N.H. Bioactive Constituents of the Stem Bark of Mitrephora glabra. Journal Natural Products, Columbus, v.72, n.11, p.1949-1953. 2009

LUNA CAZÁRES, L.M.; GONZÁLEZ-ESQUINCA ,A. R. Actividad antibacteriana de extractos de Annona purpurea y Annona diversifolia. Polibotánica, México, v.25, p.121-125, 2008.

L U N A - C A Z A R E S , L . M .; G O N Z Á L E Z - ESQUINCA, A.R. Susceptibility of bacteria and complete spheroplasts of Escherichia coli, Pseudomonas aeruginosa and Salmonella Typhi to rolliniastatin-2. Natural Product Research, Milton Park, UK, v.24, n.12, p.1139-1145, 2010.

MCKEY, D. Adaptive patterns in alkaloid physiology, The American Naturalist, Illinois, v.108, p.305-320, 1974.

MOREIRA, D.L.; LEITÃO, G.G. Quantitative determination of liriodenine and moupinamide in five species of Mollinedia by high performance liquid chromatography. Phytochemical Analysis, Wolverhampton v.12, p. 223-225, 2001.

OROZCO CASTILLO, J.A. Efecto del nitrógeno en la producción de alcaloides en plántulas de Annona diversifolia Saff. 2009. 101 f. Tesis (Licenciatura en Biología) - Universidad de Ciencias y Artes de Chiapas, México, 2009.

PARRA-GARCÉS, M. I.; CAROPRESE-ARAQUE, J. F.; ARRIETA-PRIETO, D.; \& STASHENKO, E. Morphology, anatomy, ontogeny and chemical composition of inflorescences volatile secondary metabolites of Lippia alba (Verbenaceae) at three stages of development. Revista de Biología Tropical, Costa Rica, v. 58, p. 1533. 2010.

RE JÓ N - O RANTE S, J.D.; G ONZ Á LEZ ESQUINCA, A.R.; DE LA MORA, M.P.; ROLDAN, G.; CORTES, D. Annomontine, an alkaloid isolated from Annona purpurea, has anxiolytic-like effects in the elevated plus-maze. Planta Médica, Stuttgart, v.77, n.4, p.322-327, 2011.

RILEY SALDAÑA, C. Actividad antimicrobiana y Citotóxica de Annona diversifolia. 2007. 82 f. Tesis (Licenciatura en Biología) - Universidad de Ciencias y Artes de Chiapas, México, 2007. 
SCHLIE-GUZMÁN, M.A.; GARCÍA- WOO, S.H.; SUN, N.J.; CASSADY, J.M.; CARRANCÁ, A.; GONZÁLEZ-ESQUINCA, SNAPKA, R.M.; Topoisomerase II inhibition by A.R.. In vitro and in vivo antiproliferative activity aporphine alkaloids. Biochemical Pharmacology, of laherradurin and cherimolin-2 of annona Kansas City, v.57, n.10, p.1141-1145, 1999.

diversifolia saff. Phytotherapy Research, London, v.23, n.8, p.1128-1133, 2009.

STAMP, N. Out of the quagmire of plant defense hypotheses The Quarterly Review of Biology, Chicago, v.78, n.1, p.23-55, 2003.

S U R E S H , H . M .; S H I VA K U M A R, B.; SHIVAKUMAR, S.I. Phytochemical Potential of Annona reticulata roots for antiproliferative activity on human cancer cell lines. Advances in Life Sciences, Tokyom v.2, n.2, p.1-4, 2012.

WATERMAN P. G. Chemistry of the annonaceae. Structures of uvarindoles A-D, four new benzylated indole alkaloids from Uvaria angolensis. Journal of the Chemical Society, Cambridge, v.19, p.1280- 1281, 1984.

WOO, S.H.; REYNOLDS, M.C.; SUN, N.J.; CASSADY, J.M.; SNAPKA, R.M. Inhibition of Topoisomerase II by Liriodenine. Biochemical WU, C.C.; WU, C.L.; HUANG, S.L.; CHANG. H.T. Antifungal activity of Liriodenine from Michelia formosana heartwood against wood-rotting fungi. Wood Science and Technology, New York, v.46, n.4, p.737-747, 2011.

XIE, Y.; WANG, J.; YANG, F.; LE, C. Comparative analysis of essential oil components of two Cryptomeria species from China industrial. Industrial Crops and Products, Amsterdam, v.34, p.1226-1230, 2011.

YOU MIN, D. H. M.; WICKRAMARANTHE, S. G. L.; CHAI, H.; CHAGWEDERA, T.E.; FA R N W O RT H, N . R . ; C O R D E L L, G . A . ; KINGHORN, A.D.; PEZZUTO, J.A H. Roemerine, an aphorfine alkaloid from Annonas enegalensis that reverses the multidrug-resistence phenotype with cultured cells. Journal Natural Products, Ohio, v.8, n.4, p.598-604, 1995.16

Pharmacology, Kansas City, v.54, p.467-473, 1997. 